\title{
Properties of some Bacteriocins Produced by Rhizobium trifolii
}

\author{
By E. A. SCHWINGHAMER \\ Division of Plant Industry, C.S.I.R.O., Canberra, A.C.T. 2601, Australia
}

(Received 4 March 1975; revised 30 June 1975)

\begin{abstract}
SUMMARY
Bacteriocins produced by six strains of Rhizobium trifolii were found to be of the relatively low molecular weight, non-phage type. The molecular weights ranged from approximately $\mathrm{I} \cdot 8 \times 10^{5}$ to $2.0 \times 10^{5}$. All were of protein composition, as indicated by buoyant density $\left(\mathrm{I} \cdot 32\right.$ to $\left.\mathrm{I} \cdot 34 \mathrm{~g} / \mathrm{cm}^{3}\right)$ in $\mathrm{CsCl}$ and by sensitivity to proteolytic enzymes. They were resistant to RNAase but sensitive to DNAase. The six bacteriocins could further be separated into two subgroups on the basis of sensitivity to extremes of $\mathrm{pH}$, binding to filter membranes, activity spectrum on sensitive strains of $R$. trifolii, and possibly mode of action on sensitive bacteria. Bacteriocin production occurred spontaneously during the early- to mid-exponential phase of bacterial growth in broth culture.
\end{abstract}

\section{INTRODUCTION}

There have been several reports of bacteriocin production by the rhizobia (Roslycky, 1967; Schwinghamer, 197I ; Lotz \& Mayer, 1972; Schwinghamer, Pankhurst \& Whitfeld, I973) but little is known about the genetic determinants or about the nature of the substances. Two of the reports dealt with the structural nature of single bacteriocins, which were shown to be phage tail-like particles (Lotz \& Mayer, 1972) or defective phage particles (Schwinghamer et al. 1973).

This paper examines some characteristics of other, smaller bacteriocins produced by Rhizobium trifolii which are clearly different from the phage-like types and may be a commonly occurring form in this species.

\section{METHODS}

Bacteria and media. The bacteriocinogenic (bacteriocin-producing) strains of Rhizobium trifolii and their sources are listed in Table I. Indicator strains of $R$. trifolii are TAI, CC24I and $\mathrm{CC} 276$ from a strain collection maintained at C.S.I.R.O., Canberra, and TI5 isolated from a clover nodule near Sutton, New South Wales, Australia. The one strain of R. leguminosarum, L6, was originally obtained as No. 128c5 from the Nitragin Co., Milwaukee, Wisconsin, U.S.A. All strains were subcultured and confirmed as rhizobia in nodule tests on the appropriate host plants.

The temperate phage, $\phi$ Tiо, was obtained from lysogenic strain Tro of $R$. trifolii and subsequently maintained on another strain of $R$. trifolii, Tr.

A modified form of Bergersen's synthetic medium (Bergersen, I96I) was used for maintenance of strains, production of bacteriocins and assay of bacteriocin activity. The amounts of sodium glutamate and mannitol/1 medium were reduced to 0.5 and $2.0 \mathrm{~g}$, respectively, and yeast extract (Difco) was added $(0.4 \mathrm{~g} / \mathrm{l})$ to stimulate growth. 
Table I. Source and specificity of action of some bacteriocins (small, nonphage type) produced by Rhizobium trifolii

\begin{tabular}{|c|c|c|c|c|c|c|}
\hline \multirow[b]{2}{*}{ Subgroup } & \multirow[b]{2}{*}{ Bacteriocin } & \multirow[b]{2}{*}{$\begin{array}{l}\text { Strain of } \\
\text { bacterio- } \\
\text { cinogenic } \\
\text { bacteria }\end{array}$} & \multirow[b]{2}{*}{$\begin{array}{c}\text { Source (all in Australia) of bacterial } \\
\text { strain }\end{array}$} & \multicolumn{3}{|c|}{ on indicator strains: } \\
\hline & & & & $\begin{array}{c}\text { TAI } \\
\text { or } \\
\text { CC276 }\end{array}$ & $\begin{array}{c}\text { TI5 } \\
\text { or } \\
\text { CC24I }\end{array}$ & L6 \\
\hline Ia & $\begin{array}{r}782 \\
52\end{array}$ & $\begin{array}{l}\text { CB782 } \\
\text { R52 }\end{array}$ & $\begin{array}{l}\text { CSIRO Canberra collection } \\
\text { Clover nodule, New South Wales }\end{array}$ & $\begin{array}{l}+ \\
+\end{array}$ & $\begin{array}{l}- \\
-\end{array}$ & $\begin{array}{l}+ \\
+\end{array}$ \\
\hline Ib & $\begin{array}{r}6 \text { I I } \\
\text { II I } \\
4 \\
\text { I I }\end{array}$ & $\begin{array}{l}\text { RO6I I } \\
\text { ROI I I } \\
\text { Tr4 } \\
\text { TrI I }\end{array}$ & $\begin{array}{l}\text { Clover nodule, Victoria } \\
\text { Clover nodule, Victoria } \\
\text { Clover nodule, New South Wales } \\
\text { Clover nodule, New South Wales }\end{array}$ & $\begin{array}{l}- \\
- \\
- \\
-\end{array}$ & $\begin{array}{l}+ \\
+ \\
+ \\
+\end{array}$ & $\begin{array}{l}+ \\
+ \\
+ \\
+\end{array}$ \\
\hline
\end{tabular}

Growth and bioassay of bacteriocins. For production of bacteriocins, bottles of broth were inoculated with fresh agar-grown bacteria and incubated for about $2 \mathrm{I} \mathrm{h}$ on a shaker (IIO rev./min at $29^{\circ} \mathrm{C}$ ). Cultures with satisfactory levels of bioactivity could be stored at $4{ }^{\circ} \mathrm{C}$ for up to several months with little loss of activity.

Samples to be assayed for bacteriocin activity were diluted, exposed to chloroform ( $\mathrm{I}$ drop/r to $2 \mathrm{ml}$ ), and tested on appropriate indicator bacteria by standard spot-test procedures (Mayr-Harting, Hedges \& Berkeley, 1972). Total activity of samples was expressed in arbitrary units (u) corresponding to the reciprocal of the dilution end-point for detectable spot activity. Occasional checks for possible phage activity were made for all bacteriocinproducing strains by standard phage plaque tests.

Concentration and partial purification of bacteriocins. Cultures with a satisfactory level of activity (i.e. dilution end-point $\geqslant 1000$ ) were centrifuged at $10000 \mathrm{~g}$ for $25 \mathrm{~min}$. Bacteriocins of subgroup Ib (Table I) were precipitated from supernatant fluids by ammonium sulphate, although at much lower levels of activity than previously obtained with a phage-like bacteriocin (Schwinghamer et al. 1973). Solid ammonium sulphate was stirred into the chilled supernatant to the 45 to $48 \%$ saturation level. After overnight storage at $4{ }^{\circ} \mathrm{C}$ the bacteriocins were sedimented by centrifugation at $24000 \mathrm{~g}$ for $\mathrm{I} \mathrm{h}$ and resuspended in a small volume of 0. I M-ammonium acetate. Ammonium sulphate concentrations below $45 \%$ saturation gave lower yields of bacteriocin; concentrations greater than 48 to $50 \%$ saturation gave improved yields but were unsatisfactory because of excessive precipitation of polysaccharides or other polymeric substances.

Bacteriocins produced by $\mathrm{CB} 782$ or $\mathrm{R} 52$ were only poorly precipitable by ammonium sulphate and were concentrated as follows: (i) rotary-vacuum evaporation $\left(35^{\circ} \mathrm{C}\right.$ maximum) of the supernatant fluid to approximately one-eighth of the original volume; (ii) removal of the bulk of the polysaccharide material to reduce the viscosity of the concentrate, by treatment with DEAE-dextran (mol. wt 2000000; Pharmacia); (iii) further concentration (about fivefold) by membrane ultrafiltration, using XM-rooA or XM-300 Diaflo membranes (Amicon Corp., Lexington, Massachusetts, U.S.A.); (iv) for maximum concentration, repetition of steps (ii) and (iii), with distilled water or phosphate buffer $(0.005 \mathrm{M}, \mathrm{pH} \mathrm{7.2)}$ as diluent for the filtration steps. In the DEAE-dextran treatment, a $\mathrm{I} \cdot 0 \%$ aqueous solution of DEAE-dextran was added dropwise to the chilled viscous concentrate at about I drop $/ \mathrm{ml}$, with mild swirling, to induce 'thread' formation and aggregation of anionic polymers. The mucilaginous precipitate was removed by centrifugation at $12000 \mathrm{~g}$ for $15 \mathrm{~min}$. In all of the above concentration procedures except rotary evaporation, the samples were maintained at 
about $5{ }^{\circ} \mathrm{C}$. Activity of these non-sterile concentrates could be maintained for several days at $4{ }^{\circ} \mathrm{C}$, but for longer periods samples were stored frozen.

Equilibrium density gradient centrifugation in $\mathrm{CsCl}$. Preliminary experiments had indicated that several of the bacteriocins banded near the centre of the tube when $30 \%(\mathrm{w} / \mathrm{w}) \mathrm{CsCl}$ was used, but prolonged exposure to this concentration of the salt resulted in loss of activity. A two-step, $4 \mathrm{ml}$ initial gradient (Brunk \& Leick, 1969) was therefore used to minimize inactivation of bacteriocins. The lower $2.0 \mathrm{ml}$ step contained $40 \%(\mathrm{w} / \mathrm{w}) \mathrm{CsCl}$ (Sequanal Grade, Pierce Chemical Co., Rochford, Illinois, U.S.A.) in 0.0I5 M-tris-HCl

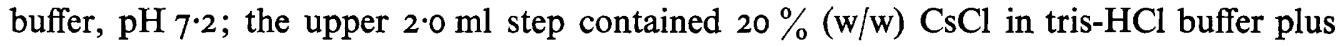
bacteriocin sample. The tubes were topped with a $\mathrm{I} \cdot 2 \mathrm{ml}$ layer of paraffin oil and centrifuged (Spinco SW 50 rotor, temperature $9{ }^{\circ} \mathrm{C}$ ) at $165000 \mathrm{~g}$ for 22 to $24 \mathrm{~h}$. Fractions ( 9 drops) were collected through the bottom of tubes mounted in a puncturing device. Small portions of each fraction were diluted in broth and assayed to determine the bacteriocin peak. Buoyant density determinations were based on refractive index measurements (Abbe refractometer) taken for fractions on both sides of the activity peak. Fractions representing the peak of activity, as well as 'pre-peak' and 'post-peak' portions of the gradient, were pooled for further examination by electron microscopy or analytical ultracentrifugation.

Density-gradient centrifugation in glycerol. Glycerol density gradients (8 to $32 \%$, w/w) were prepared by carefully pipetting $\mathrm{I} \cdot \mathrm{I} 5 \mathrm{ml}$ layers of $32,24, \mathrm{I} 6$, and $8 \%$ glycerol (in $0 \cdot 0 \mathrm{I} \mathrm{M}$ tris- $\mathrm{HCl}, \mathrm{pH} 7 \cdot 3$ ) into $5 \mathrm{ml}$ cellulose nitrate tubes and allowing the solutions to diffuse at $4{ }^{\circ} \mathrm{C}$ overnight to produce a nearly linear gradient of density. Samples $(0.3 \mathrm{ml})$ of bacteriocin concentrates or of reference enzymes were layered and the tubes centrifuged for the indicated time in an SW 50 rotor at $\mathrm{I}_{5} \mathrm{I} 000 \mathrm{~g}$ and a rotor temperature of 9 to $10{ }^{\circ} \mathrm{C}$. Fractions $(8$ to Io drops, depending on the experiment) were collected and assayed as described for $\mathrm{CsCl}$ gradients.

The two reference enzymes used for molecular weight estimation - yeast alcohol dehydrogenase ( $2 \times$ crystallized; Sigma) and bovine liver catalase (Sigma) - were dissolved in 0.02 Mphosphate buffer $\mathrm{pH} 7 \cdot 2$ at $\mathrm{I} \cdot 5 \mathrm{mg} / \mathrm{ml}$; the amount of enzyme added per gradient was therefore $450 \mu \mathrm{g}$. Alcohol dehydrogenase (ADH) activity in glycerol gradient fractions was measured by adaptation of a method used for detection of dehydrogenases in gels (see Vesell \& Bearn, 1962). Enzymic oxidation of ethyl alcohol was followed colorimetrically (550 nm) in the presence of $0.6 \mathrm{~mm}$ - $\beta$-nicotinamide adenine dinucleotide (Sigma), 0.3 mM- $p$-nitroblue tetrazolium (Calbiochem), and $0.2 \mathrm{mM}$-phenazine methosulphate (Calbiochem) in $0.0 \mathrm{I} \mathrm{M}$ tris- $\mathrm{HCl}$ buffer, $\mathrm{pH} 8 \cdot 8$. Catalase activity was assayed by measuring the decrease in extinction at $240 \mathrm{~nm}$ per $30 \mathrm{~s}$ interval in a reaction mixture containing $0.2 \% \mathrm{H}_{2} \mathrm{O}_{2}, 0.0 \mathrm{I}$ M-phosphate $\mathrm{pH} 7 \cdot 0$, and diluted samples of fractions being tested.

Sensitivity ofbacteriocins to enzymes. Enzymes used for sensitivity tests were the following: lysozyme $(3 \times$ crystallized; Pentex Inc., Kankakee, Illinois, U.S.A.); ribonuclease (RNAase I, I $\times$ crystallized, beef pancreas; Sigma); deoxyribonuclease (DNAase I, beef pancreas; Sigma); protease (type VI, from Streptomyces griseus; Sigma); pronase (B grade; Calbiochem). Enzymes were added to supernatant fluids containing bacteriocins or to supernatant fluids concentrated 3- to 4-fold by ultrafiltration, with buffers and salts at concentrations as given in Results. Samples were incubated for $70 \mathrm{~min}$ at $3 \mathrm{I}{ }^{\circ} \mathrm{C}$, then assayed for residual bacteriocin activity. Control treatments included buffers alone and heat-treated $\left(85^{\circ} \mathrm{C}\right.$ for I5 min) or autoclaved (I03.5 $\mathrm{kPa}$, IO min) enzymes.

Sensitivity of bacteriocins to ultraviolet light. Bacteriocins were irradiated with u.v. light by exposing stirred suspensions for various times $(0 \cdot 33,0 \cdot 75, \mathrm{I} \cdot 5,4$ and $8 \mathrm{~min})$ at a distance of $25 \mathrm{~cm}$ from a $\mathrm{I} 5 \mathrm{~W}$ germicidal lamp ( $90 \%$ emission at $253.7 \mathrm{~nm}$ ). 
Electron microscopy. Droplets of samples from $\mathrm{CsCl}$ or glycerol gradients were deposited on copper grids covered with carbon-coated parlodion film. These preparations were airdried and negatively stained with $\mathrm{I} \cdot 0 \%$ phosphotungstic acid at $\mathrm{pH} 5.3$ or with $\mathrm{I} \cdot 0 \%$ uranyl acetate at $\mathrm{pH} 4.4$. Bacitracin (Nutritional Biochemical Co.) at $50 \mu \mathrm{g} / \mathrm{ml}$ was also used in some preparations as a low molecular weight spreading agent (Gregory \& Pirie, I973). Samples from peak activity fractions from $\mathrm{CsCl}$ gradients were examined directly, without dialysis pre-treatment, after 'washing' the air-dried grid preparations once with a droplet of $0 \cdot \mathrm{I} \mathrm{M}$-ammonium acetate to remove most of the $\mathrm{CsCl}$. Samples from glycerol gradients could be examined directly without this wash treatment. Grids were examined in a Philips EM 200 electron microscope at $80 \mathrm{kV}$.

\section{RESULTS}

\section{Production of bacteriocins and strain sensitivity}

The six strains of $R$. trifolii listed as bacteriocinogenic in Table I have all been shown in repeated tests to produce antibacterial (growth-inhibiting) substances which are active against at least one-third of the strains of $R$. trifolii tested as indicators but, as expected, do not inhibit the producing strains. Previous work (Schwinghamer, 197I) had suggested these substances to be bacteriocin-like in that they were not dialysable and did not produce plaques. The results summarized here mainly compare substances produced by the first four strains given in Table I, particularly CB782 and R06I I. Bacteriocins produced by these two strains are considered to be representative of the two subgroups, Ia and $I b$, which are readily distinguishable by their reciprocal specificity of action on some indicator strains (e.g. TAI and $\mathrm{CC}_{2} 76$ as compared with $\operatorname{Tr} 5$ and $\mathrm{CC} 24 \mathrm{I}$ ).

Bacteriocin was readily produced during growth on agar or in broth, although the latter medium was usect almost exclusively for harvesting purposes. There was no obvious increase of bacteriocin production after u.v. irradiation $(253.7 \mathrm{~nm})$ of strains $\mathrm{CB} 782$ or RO6II, both of which thus appear to be non-inducible. Bacteriocin production in variously modified broth media appeared to parallel growth, being low in the synthetic medium without yeast extract and maximum when yeast extract was added at about $0.4 \mathrm{~g} / \mathrm{l}$. The level of mannitol was kept low and aeration was limited to shaking at I IO rev./min to minimize polysaccharide production.

Bacteriocin production by strains $\mathrm{CB} 782$ and RO6I I was measured during growth in broth (Fig. I). The doubling time for the bacteria under the conditions of this experiment was about $4.8 \mathrm{~h}$ for $\mathrm{CB} 782$ and $5.2 \mathrm{~h}$ for RO6II. In contrast, the doubling time for bacteriocin production during the near-linear part of the total activity curve was only $2 \cdot 2 \mathrm{~h}$ for CB782 and $2.5 \mathrm{~h}$ for RO6I I. In another experiment, with strain CB782 only, the total activity peaked similarly but showed no significant decline even when the culture was grown for $38 \mathrm{~h}$. Most broth cultures, inoculated to a density of about $2 \times 10^{7}$ to $3 \times 10^{7}$ cells $/ \mathrm{ml}$, were therefore grown (at $29^{\circ} \mathrm{C}$ ) for only 19 to $2 \mathrm{I} \mathrm{h}$. Longer incubation not only failed to give higher yields of bacteriocin but also complicated bacteriocin concentration because of the accumulation of high levels of polysaccharides or debris in fully grown cultures.

\section{Concentration of bacteriocins}

Since these bacteriocins were smaller than the readily sedimentable phage-like bacteriocins, separation from polysaccharides (produced in abundance by rhizobia) was very difficult. More than $80 \%$ of the active substance was sedimented in a fixed-angle rotor at $100000 \mathrm{~g}$ for 8 to to h, but large amounts of polysaccharide-like material pelleted simultaneously and could not be effectively separated by differential centrifugation. Preliminary attempts to 


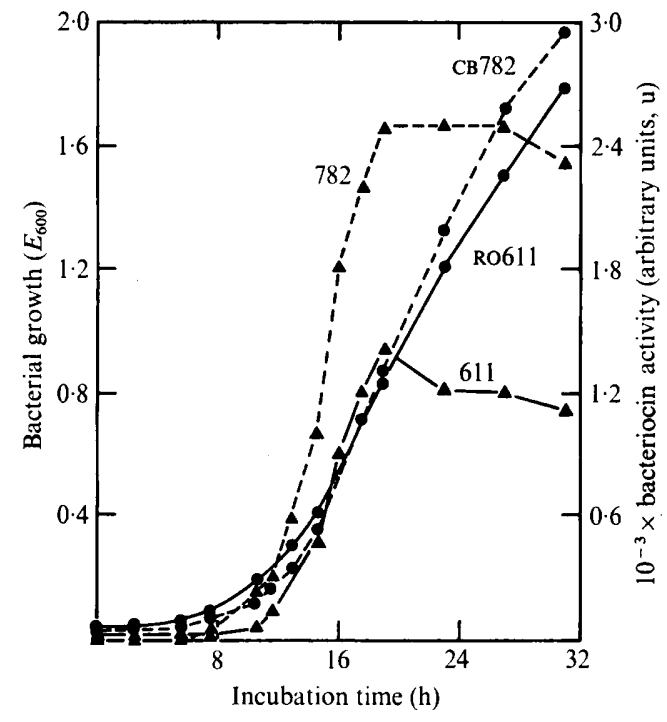

Fig. I

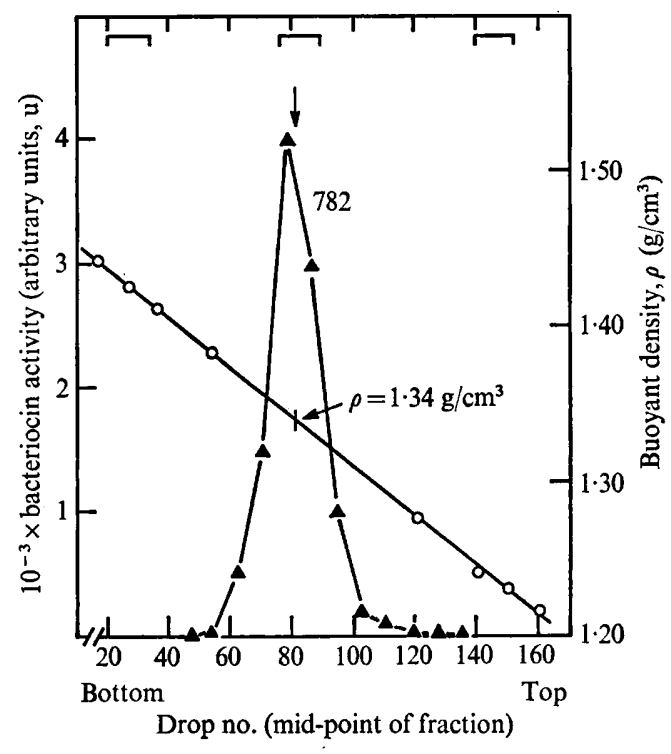

Fig. 2

Fig. I. Growth of bacteria and production of bacteriocin by $R$. trifolii strains CB782 and RO6II Bacteria were inoculated into broth (initial concentration about $2 \times 10^{7}$ cells $/ \mathrm{ml}$; see Methods) and grown in a shaker bath at $29^{\circ} \mathrm{C}$. O, Growth; $\boldsymbol{\Delta}$, bacteriocin activity. Broken lines, 782 and CB782; solid lines, 6I I and Ro6I I.

Fig. 2. Activity of bacteriocin 782 after centrifugation to equilibrium in a two-step (20 and $40 \%$, $\mathrm{w} / \mathrm{w}) \mathrm{CsCl}$ gradient. Centrifugation was in a Spinco SW 50 rotor at $165000 \mathrm{~g}$ for $24 \mathrm{~h}$. Fractions under braced zones were pooled for examination by electron microscopy. Vertical arrow indicates the peak of activity. $\boldsymbol{\Delta}$, Bacteriocin activity; $O$, buoyant density.

remove the active agent selectively from culture supernatants by biphasic separation procedures (e.g. polyethylene glycol-dextran sulphate) or by ion exchange resins also failed, apparently due to strong binding properties of the bacteriocins, particularly those of subgroup Ib. Precipitation by ammonium sulphate, at a range of salt concentrations and $\mathrm{pH}$ levels, was poor with bacteriocins 782 or 52 and only moderately effective with 6I I, due to co-precipitation of some viscous materials and to partial loss of activity in the salt solutions.

Removal of polysaccharides by the polycation DEAE-dextran (Dudman, 1972) provided the most satisfactory means of reducing viscosity to workable levels, especially for the 782 type of bacteriocin, despite the associated loss of some activity. Under favourable conditions, by alternate DEAE treatment and concentration by ultrafiltration, $500 \mathrm{ml}$ of culture supernatant fluid with an activity of about $2000 \mathrm{u} / \mathrm{ml}$ could be reduced to a $5 \mathrm{ml}$ volume of moderate viscosity with an activity of about $40000 \mathrm{u} / \mathrm{ml}$ (i.e. at an efficiency of about $20 \%$ ). At least $10000 \mathrm{u} / \mathrm{ml}$ was considered desirable for monitoring the bioactivity of density gradient fractions, but a considerably higher concentration would be needed for spectrophotometric examination or other analytical procedures.

\section{Filterability of bacteriocins}

Filtration experiments with bacteriocins 782 and $6 \mathrm{II}$ (Table 2) as well as bacteriocins 52 , 4 and I I suggested a molecular weight of roughly 200000 to 300000 and a size of Io to $20 \mathrm{~nm}$, assuming reasonably spherical particles.

The portion of 782 activity which passed through XM-300 or XM-100A membranes was 


\section{Table 2. Filterability of bacteriocins 782 and $6 \mathrm{I} \mathrm{I}$, with and without pretreatment}

\begin{tabular}{|c|c|c|c|}
\hline Bacteriocin & $\begin{array}{l}\text { Type of filter } \\
\text { membrane }\end{array}$ & $\begin{array}{l}\text { Pre-filtration treatment used to } \\
\text { alter filterability }\end{array}$ & $\begin{array}{l}\text { Activity in } \\
\text { filtrate }(\%)\end{array}$ \\
\hline 782 & $\begin{array}{l}\text { Millipore } \\
0.45 \mu \mathrm{m} \\
0.01 \mu \mathrm{m}\end{array}$ & $\begin{array}{l}\text { None } \\
\text { None }\end{array}$ & $\begin{array}{l}100 \\
<5\end{array}$ \\
\hline & $\begin{array}{l}\text { Diaflo* } \\
\text { XM-I00A } \\
\text { XM-300 }\end{array}$ & $\begin{array}{l}\text { None } \\
\text { None }\end{array}$ & $\begin{array}{r}5 \\
20\end{array}$ \\
\hline & $\begin{array}{l}\text { Millipore } \\
0.01 \mu \mathrm{m} \\
0.01 \mu \mathrm{m} \\
0.01 \mu \mathrm{m} \\
0.01 \mu \mathrm{m} \\
0.01 \mu \mathrm{m}\end{array}$ & $\begin{array}{l}\text { Filtrate from XM-IOoA or XM-300 } \\
\text { Sonication or blending } \\
\text { Triton X-10o or Brij- } 58(0 \cdot 3 \%, \mathrm{v} / \mathrm{v}) \\
\text { XM-100A filtrate of detergent-treated sample } \\
\text { Urea, } 5 \mathrm{M} \\
\text { pH lowered to } 4 \cdot 2\end{array}$ & $\begin{array}{c}<5 \\
<10^{\dagger} \\
15-30 \dagger \\
70 \\
<5 \\
<5\end{array}$ \\
\hline 611 & $\begin{array}{l}\text { Millipore } \\
0.45 \mu \mathrm{m} \\
0.45 \mu \mathrm{m} \\
0.01 \mu \mathrm{m} \\
\text { Diaflo, }{ }^{*} \text { XM-I00A }\end{array}$ & $\begin{array}{l}\text { None } \\
\text { pH lowered to } 4^{\circ} 0 \\
\text { pH lowered to } 4^{\circ} 0 \\
\text { None }\end{array}$ & $\begin{aligned} & 0 \div \\
&> 50 \\
&<5 \\
&<5\end{aligned}$ \\
\hline
\end{tabular}

* Nominal molecular weight cut-off levels for XM-100A and XM-300 are approximately 100000 and 300000 , respectively.

$\dagger$ Similar results obtained with the XM-100A membrane, for the sonication-blending or detergent treatments.

$\ddagger$ Adsorbed.

retained by the $0.01 \mu \mathrm{m}$ Millipore filter, indicating variation in pore size of the former, rather than wide variation in size of the bacteriocin particles. Mild sonication or blending of samples did not induce filterability, but the non-ionic detergents Triton X-100 or Brij-58 increased filterability significantly and the fraction appearing in the filtrate appeared to filter even more readily. Urea did not increase filterability. It appears likely that at least a portion of the active material is associated with detergent-soluble bacterial fragments.

Bacteriocins of subgroup I $b$ differed clearly from those of subgroup I a by binding strongly to Millipore membranes and were not recovered when 0.1 to $0.5 \mathrm{M}-\mathrm{NaCl}$ was passed through the inverted filter. This adsorption could, however, be minimized and the material made partly filterable through the $0.45 \mu \mathrm{m}$ filter by lowering the $\mathrm{pH}$ of the samples to $4^{\circ} 0$.

\section{Buoyant density in CsCl and electron microscopy of peak activity fractions}

The bioactivity profile for fractions collected from a typical $\mathrm{CsCl}$ equilibrium centrifugation of a bacteriocin 782 sample is shown in Fig. 2. The accuracy of determination of buoyant density by bioassay monitoring was $\pm 0.01 \mathrm{~g} / \mathrm{cm}^{3}$ for all experiments. The mean buoyant density values for bacteriocins 782,52 , and 6 I I are given in Table 3 . These values indicate a protein composition, albeit a relatively 'heavy' protein particle which could contain a small amount of denser, non-protein material.

Peak activity fractions examined by electron microscopy contained large numbers of flagella and a very few phage-like particles, but no other identifiable particles. Pre-peak and post-peak pooled fractions were similar except for a much smaller number of flagella or flagellar fragments. However, the flagella and the active material were readily separable by glycerol gradient centrifugation. The buoyant density in $\mathrm{CsCl}$ of the active, flagella-free peak material obtained from a glycerol gradient containing bacteriocin 782 was found to be $\mathrm{I} \cdot 35$ $\mathrm{g} / \mathrm{cm}^{3}$, almost identical with that of bacteriocins in crude concentrates containing flagella. 
Table 3. Buoyant density and approximate molecular weight of bacteriocins

Details of procedure for determination of buoyant density in $\mathrm{CsCl}$ and of molecular weight by sedimentation in glycerol gradients are given in Methods. Molecular weights of yeast ADH and of catalase were taken as 150000 and 250000 respectively (Martin \& Ames, 196I).

\begin{tabular}{|c|c|c|c|}
\hline \multirow[b]{2}{*}{ Bacteriocin } & \multirow[b]{2}{*}{$\begin{array}{l}\text { Buoyant density* } \\
\qquad\left(\mathrm{g} / \mathrm{cm}^{3}\right)\end{array}$} & \multicolumn{2}{|c|}{ Molecular weight* } \\
\hline & & $\begin{array}{l}\mathrm{ADH} \text { as reference } \\
\text { molecule }\end{array}$ & $\begin{array}{c}\text { Catalase as reference } \\
\text { molecule }\end{array}$ \\
\hline 782 & $\begin{array}{l}\mathrm{I} \cdot 34 \pm 0.03 \\
(\mathrm{II})\end{array}$ & $\begin{array}{c}176000 \pm 3000 \\
(2)\end{array}$ & $\begin{array}{c}178000 \pm 9000 \\
(4)\end{array}$ \\
\hline 52 & $1 \cdot 33$ & 一 & $\begin{array}{c}179000 \pm 6000 \\
(2)\end{array}$ \\
\hline $6 \mathrm{II}$ & $1 \cdot 32 \pm 0.01$ & 212000 & $\frac{196000 \pm 3000}{(2)}$ \\
\hline $\begin{array}{c}4 \\
\text { Reference } \\
\text { molecules }\end{array}$ & - & 207000 & 195000 \\
\hline ADH (yeast) & & - & $\begin{array}{c}142000 \pm 1000 \\
(3)\end{array}$ \\
\hline Catalase & - & $\begin{array}{c}265000 \pm 1000 \\
\text { (3) }\end{array}$ & 一 \\
\hline
\end{tabular}

\footnotetext{
* Standard error and number of determinations (in parentheses) are given for means; other values represent single determinations.
}

A high activity sample obtained from pooled peak fractions of several preparative $\mathrm{CsCl}$ centrifugation experiments was treated with sodium dodecyl sulphate $(3 \%, \mathrm{w} / \mathrm{v})$ and examined for the presence of nucleic acid by analytical centrifugation in $\mathrm{CsCl}$, a procedure used previously to detect DNA in bacteriocin 37 (Schwinghamer et al. 1973). No definite band of material absorbing at $260 \mathrm{~nm}$ could be detected, but a disperse background level of absorbance, presumably due to dissociated flagellar material, could have masked the presence of a small amount of nucleic acid.

\section{Molecular weight of bacteriocins}

Polysaccharide could be readily pelleted and separated from the bacteriocins in $\mathrm{CsCl}$ gradients but not in sucrose or glycerol gradients. However, when DEAE-dextran was used to remove the bulk of the interfering polysaccharides, sucrose ( 5 to $20 \%$ ) and glycerol ( 8 to $32 \%$ ) density gradients could be used successfully to determine approximate molecular size. Glycerol was used for all the experiments described because of the somewhat better retention of bacteriocin activity than in sucrose, and because it is more suitable for direct observation of non-dialysed fractions by electron microscopy.

The distribution of catalase, yeast $\mathrm{ADH}$, and bacteriocin 782 was compared after $6 \mathrm{~h}$ of centrifugation in glycerol gradients (Fig. 3). Bacteriocin and enzyme samples were layered on separate gradient tubes to avoid interaction or interference between these materials. Adding a mixed sample of catalase and 782 (or 52) caused the bacteriocin peak to move much faster and to spread out over a wide range of density. The 'distance' of migration in these experiments was taken as the number of drops from the midpoint of the sample layer to the peak of activity (estimated to the nearest drop on the basis of the symmetrical part of the activity curve).

The relationship between migration distance and time of centrifugation under a given set 


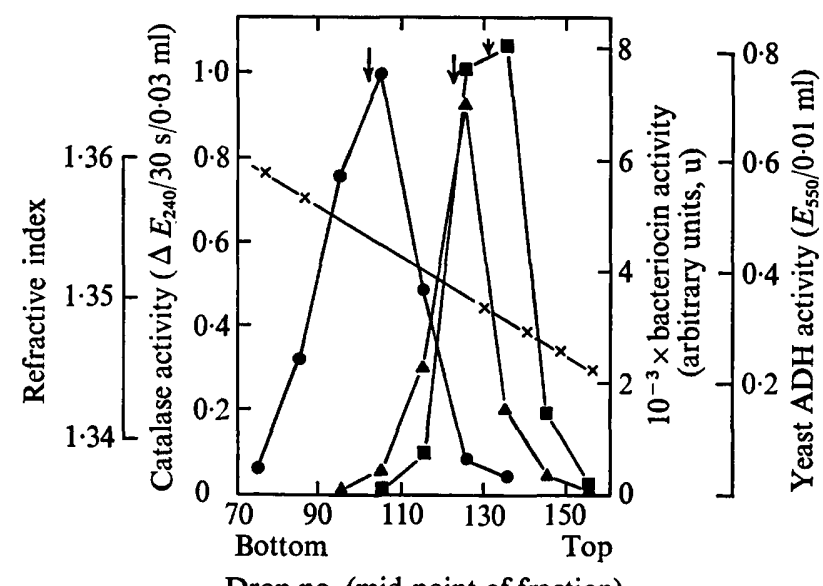

Drop no. (mid-point of fraction)
Fig. 4

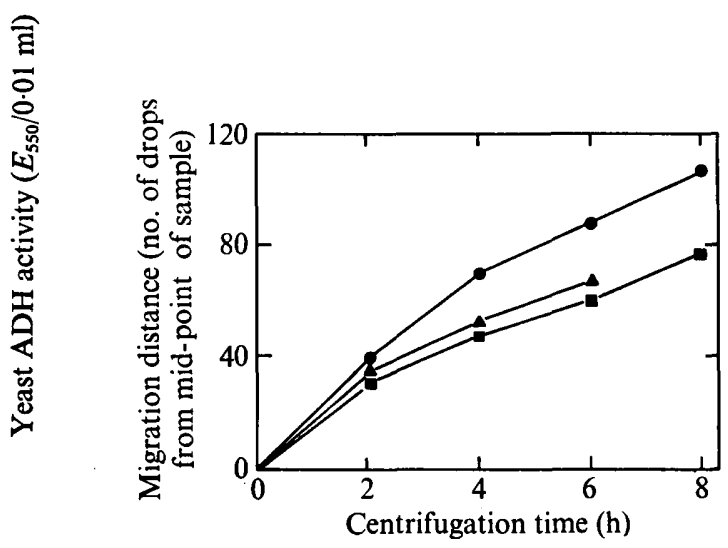

Fig. 3

Fig. 3. Activity of bacteriocin $782(\Delta)$ and the two reference enzymes, catalase $(\Theta)$ and yeast ADH (D), after centrifugation for $6 \mathrm{~h}$ in a 8 to $32 \%(\mathrm{w} / \mathrm{w})$ glycerol gradient at $151000 \mathrm{~g}$. Arrows indicate the estimated peaks of activity, from which migration 'distance' (no. of drops between the peak and the mid-point of the added sample layer) was determined. Refractive index $(x)$ measurements indicate linearity of density.

Fig. 4. Migration 'distance' of bacteriocin $782(\Delta)$ and two reference enzymes, catalase $(\mathbf{O})$ and yeast ADH $(\square)$ in a glycerol density gradient, as a function of time of centrifugation. Samples $(0.3 \mathrm{ml})$ were layered on separate glycerol gradients $(8$ to $32 \%, w / w)$ and centrifuged in a Spinco $\mathrm{SW}_{50}$ rotor at $\mathrm{I}_{5} \mathrm{I} 000 \mathrm{~g}$ and $9^{\circ} \mathrm{C}$. Each point represents the migration values as determined from the assay of fractions of one gradient, as in Fig. 3.

of experimental conditions (temperature, speed, type of rotor, type of gradient) is shown in Fig. 4 for bacteriocin 782 and the two reference enzymes. Migration was essentially linear for all three substances in the 4 to $8 \mathrm{~h}$ range, and further experiments (with 782 and other bacteriocins) were therefore done within this range of centrifugation time. The faster movement during the first $2 \mathrm{~h}$ may result from the relatively greater dilution of the upper portion of the gradient by the sample, an effect that became minimal after the materials had moved through this zone and linearity in glycerol density was established.

Approximate molecular weights were calculated from the ratio of the migration distance of a bacteriocin relative to that of the reference enzymes (Martin \& Ames, I96I), for four bacteriocins (Table 3). Bacteriocins 782 and 52 (mol. wt about $\mathrm{I} 80000$ ) appeared to be somewhat smaller than 6I I and 4 (mol. wt about 200000). These determinations are only approximations since they do not involve any measurements of partial specific volume or shape of molecule, but the reasonably close agreement of calculated and known molecular weight for the two reference enzymes indicates that the gradient conditions were suitable for estimation of bacteriocin size. The estimated molecular weights of the bacteriocins are also in reasonable agreement with the data from filtration experiments.

\section{Sensitivity to enzymes}

All of the bacteriocins were resistant to treatment with lysozyme $(300 \mu \mathrm{g} / \mathrm{ml} ; 0.02 \mathrm{M}-$ $\mathrm{NaCl}+0.0$ I M-phosphate buffer, $\mathrm{pH} 6.8)$ or RNAase $(200 \mu \mathrm{g} / \mathrm{ml} ; 0.0 \mathrm{I} \mathrm{M}$-tris-HCl, pH 7.2) for $70 \mathrm{~min}$ at $3 \mathrm{I}{ }^{\circ} \mathrm{C}$. They were fully sensitive to protease or pronase $\left(20 \mu \mathrm{g} / \mathrm{ml} ; 0.0 \mathrm{I} \mathrm{M}-\mathrm{CaCl}_{2}\right.$ $+0.005 \mathrm{M}$-tris- $\mathrm{HCl}, \mathrm{pH} 7 \cdot 3$ ), as expected from the protein composition indicated by their buoyant density in $\mathrm{CsCl}$ but, unexpectedly, were also sensitive to DNAase (30 or $50 \mu \mathrm{g} / \mathrm{ml}$; 


\title{
Table 4. Effect of buffer or salts background on the sensitivity of bacteriocin 782 to DNAase and protease
}

The inhibitory effect of EDTA on activity and its prevention by prior exposure to $\mathrm{CaCl}_{2}$ also occurred with bacteriocins $52,6 \mathrm{II}$ and 4 ; the effect of $\mathrm{Ca}^{2+}$ or tris- $\mathrm{HCl}$ on DNAase action was tested only with 782 .

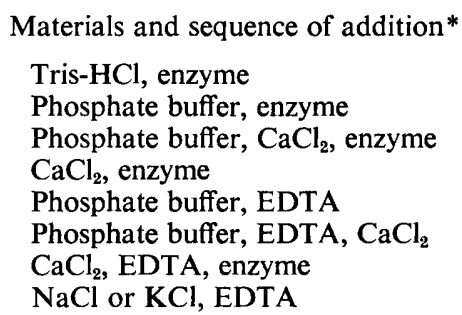

\begin{tabular}{|c|c|c|}
\hline \multicolumn{3}{|c|}{ Bacteriocin activity } \\
\hline \multirow{2}{*}{$\begin{array}{l}\text { Without } \\
\text { enzyme }\end{array}$} & \multicolumn{2}{|c|}{ With enzyme } \\
\hline & DNAase & Protease \\
\hline+ & + & - \\
\hline+ & - & - \\
\hline+ & + & - \\
\hline+ & + & - \\
\hline- & & \\
\hline- & & \\
\hline+ & + & - \\
\hline- & & \\
\hline
\end{tabular}

\begin{abstract}
* $\mathrm{MgSO}_{4}$ was added to the bacteriocin in all treatments, before the addition of other materials. The reagents were used at the following concentrations: $\mathrm{MgSO}_{4}, 5 \mathrm{mM}$; tris- $\mathrm{HCl}, 5 \mathrm{mM}$; phosphate buffer, $5 \mathrm{~mm}$; $\mathrm{CaCl}_{2}, 5 \mathrm{~mm}$;EDTA, I mM; $\mathrm{NaCl}$ or KCl, $20 \mathrm{~mm}$; DNAase, $50 \mu \mathrm{g} / \mathrm{ml}$; protease, $20 \mu \mathrm{g} / \mathrm{ml}$. All treatments at pH $7 \cdot 2,3{ }^{\circ} \mathrm{C}$, for $70 \mathrm{~min}$. Autoclaved enzyme controls did not inactivate the bacteriocins.
\end{abstract}

$0.005 \mathrm{M}-\mathrm{MgSO}_{4}+0.005 \mathrm{M}$-phosphate, $\mathrm{pH} 7 \cdot 2$ ). Inactivation of bacteriocins 782 and $6 \mathrm{II}$ by DNAase was observed in repeated experiments involving two enzyme stocks and bacteriocin samples obtained from different subcultures of strains CB782 and RO6II. The possibility of protease contamination in the DNAase samples was examined by comparing the enzymes in different buffer or salt backgrounds (Table 4 ). With tris buffer or $\mathrm{CaCl}_{2}$ the bacteriocins were inactivated by protease but not by DNAase, suggesting that protease contamination was not involved in the DNAase results. EDTA could not be used as a chelator of $\mathbf{M g}^{2+}$ ions to inhibit DNAase because it was strongly inhibitory to the bacteriocins; $\mathrm{Ca}^{2+}$ protected the bacteriocins when added before, but not after, the EDTA. The monovalent cations $\mathrm{Na}^{+}$or $\mathrm{K}^{+}$did not protect them.

Results very similar to those of Table 4 were obtained when no $\mathrm{MgSO}_{4}$ was added to the bacteriocin-salt-enzyme mixtures. $\mathrm{MgSO}_{4}$ was present in the original culture medium at a concentration of $0.4 \mathrm{mM}$, and apparently the level of $\mathrm{Mg}^{2+}$ remaining in the unconcentrated bacteriocin samples or even in samples concentrated by membrane ultrafiltration was adequate for DNAase activity.

Ethidium bromide binds to DNA and has been reported to inhibit DNAase I (Eron \& McAuslan, 1966). Bacteriocin 782, incubated for $20 \mathrm{~min}$ in DNAase buffer with ethidium bromide at 10 or $100 \mu \mathrm{g} / \mathrm{ml}$ (not inhibitory to the bacteriocin) before addition of DNAase, remained sensitive to the enzyme, suggesting that there is no DNA in the bacteriocin.

\section{Some other properties of the bacteriocins}

There was no apparent difference between bacteriocins of the two subgroups in their sensitivity to heat treatment. All were heat-labile, with at least $90 \%$ of the activity being destroyed by heating at $60^{\circ} \mathrm{C}$ for I $5 \mathrm{~min}$. Those of subgroup Ia were more tolerant to alkaline conditions and retained full activity within a $\mathrm{pH}$ range of about 4.2 to 10 ; bacteriocins of subgroup $\mathrm{Ib}$ were more tolerant to lower $\mathrm{pH}$ and retained their activity within a $\mathrm{pH}$ range of about 3.5 to 9 .

The sensitivity of bacteriocins 782 and 6 I I to u.v. radiation was compared with that of 
rhizsbiop.ag $2 \phi$ Tro. There was no measurable loss of bacteriocin activity even at the maximum exposure of $8 \mathrm{~min}$ where survival of the phage was less than $0.01 \%$, suggesting absence of functional nucleic acid in the bacteriocins.

Observations on mode of action of the bacteriocins were limited to a few experiments in which bacteria of sensitive strains were either grown in the presence of added bacteriocin or grown in mixed culture in the presence of bacteria of a bacteriocinogenic strain. Under these conditions, the action of bacteriocins 782 and 52 on bacteria of strain TAI appeared to be largely bacteriostatic. Bacteriocins $6 \mathrm{I}$ I and 4 were strongly bactericidal to bacteria of strain TI5. The two sub-groups of bacteriocins may therefore differ in mode of action as well as in other characteristics already noted (specificity of action, filterability, and tolerance to extremes of $\mathrm{pH}$ ).

\section{DISCUSSION}

There are at least two types of bacteriocins or bacteriocin-like substances produced by $R$. trifolii, differing in structure or composition. The first type is represented by defective phage particles (Schwinghamer et al. 1973). The two strains producing these particles were both inducible by u.v. light and the particles were very similar in morphology and in buoyant density in $\mathrm{CsCl}$. The second main type includes the lower molecular weight (about I80000 to 200000) bacteriocins described here. Although similar in size, buoyant density, and sensitivity or resistance to some enzymes, these bacteriocins differ sufficiently (e.g. in specificity of action and adsorption to filter membranes) to warrant further separation into two subgroups. The smaller type of bacteriocin occurs more commonly than the phage-like type among the strains of $R$. trifolii which were found to produce bacteriocin-like substances in culture, but nothing is known about the prevalence or relative importance of either type in nature.

The morphology of these 'small' bacteriocins could not be determined. Further concentration and purification will be needed for positive identification of the active substance by electron microscopy. The buoyant density and sensitivity to protease indicate protein (a characteristic of all known bacteriocins) but there may also be a minor non-protein moiety (carbohydrate, lipid or nucleic acid), as indicated for some bacteriocins of other bacteria (Bradley, 1967; Reeves, 1972). In particular, sensitivity to DNAase provides indirect evidence for DNA being present and essential for activity, although it is difficult to reconcile the presence of functional DNA in a molecule of molecular weight 200000 and of buoyant density (in $\mathrm{CsCl}$ ) $\mathrm{I} \cdot 34 \mathrm{~g} / \mathrm{cm}^{3}$. The possibility of some proteolytic enzyme activity in the DNAase samples was discounted but not fully excluded in the experiments. Non-enzymic loss of bacteriocin activity as a result of non-specific complexing with nuclease, known to occur with RNAase and some RNA viruses (Loring, 1942), is possible even though dilution of DNAase-treated samples did not promote the expected recovery of bacteriocin activity. DNA has been shown to occur only in some of the large, phage-like bacteriocins, and bactericidal action appears to be restricted to the protein component of these particles (Bradley, 1967; Reeves, 1972).

Aside from sensitivity to DNAase, the bacteriocins described are exceptional also in their sensitivity to EDTA, in their interaction with catalase in glycerol gradients, in the effect of $\mathrm{pH}$ or non-ionic detergents on their membrane filtration behaviour, and in the apparently bacteriostatic effect of bacteriocins 782 and 52 on sensitive bacteria. A bactericidal mode of action is characteristic of most bacteriocins produced by other genera of bacteria.

The possibility that antibacterial substances may confer on the producing strains of rhizobia a competitive advantage under field conditions was briefly considered in the 
previous reports for antibiotics, phage, or bacteriocins (Schwinghamer, 1971) and for a phage-like bacteriocin (Schwinghamer et 'al. 1973). The lower molecular weight forms of bacteriocins described in this paper could conceivably also play a significant role in the intense growth competition between rhizobia in the rhizosphere or in the rhizoplane of legume root systems. Production of these bacteriocins occurs spontaneously during growth of the bacteria in a comparatively non-rich medium, without the added requirement for some inducing agent normally present in the soil or excreted by the plant roots. Preliminary experiments with growth of a mixture of bacteriocinogenic bacteria and sensitive bacteria in broth suggest a considerable degree of suppression of the sensitive bacteria. It remains to be demonstrated, however,'that these agents are produced abundantly under natural conditions and do in fact enhance the capacity of a strain to outgrow other rhizobia in the rhizosphere and nodulate the homologous legume host plant.

I thank S. Craig (Division of Plant Industry electron microscope unit) for assistance in the electron microscopy portion of this work, and W. F. Dudman, P. R. Whitfeld and T. J. Higgins for helpful suggestions concerning experimental procedure.

\section{REFERENCES}

BERGERSEN, F. J. (1961). The growth of Rhizobium in synthetic media. Australian Journal of Biological Science I4, 349-360.

BradLEY, D. E. (1967). Ultrastructure of bacteriophages and bacteriocins. Bacteriological Review's 3I, 230314.

Brunk, C. F. \& LeICK, V. (1969). Rapid equilibrium isopycnic CsCl gradients. Biochemica et biophysica acta I79, I36-I 44 .

DudMAN, W. F. (1972). Detection of acidic polysaccharides in gels by DEAE-dextran. Analytical Biochemistry 46, 668-673.

ERoN, L. J. \& MCAuslan, B. R. (I966). Inhibition of deoxyribonuclease action by actinomycin D and ethidium bromide. Biochimica et biophysica acta 114, 633-636.

Gregory, D. W. \& PIRIE, B. J. S. (I973). Wetting agents for biological electron microscopy. I. General considerations and negative staining. Journal of Microscopy 99, 26I-265.

LORING, H. S. (1942). The reversible inactivation of tobacco mosaic virus by crystalline ribonuclease. Journal of General Physiology 25, 497-505.

LOTZ, W. \& MAYER, F. (1972). Isolation and characterization of a bacteriophage tail-like bacteriocin from a strain of Rhizobium. Journal of Virology 9, 160-1 73.

MARTIN, R. G. \& AMEs, B. N. (I96I). A method for determining the sedimentation behaviour of enzymes: application to protein mixtures. Journal of Biological Chemistry 236, I372-I 379.

Mayr-Harting, A., Hedges, A. J. \& Berkeley, R. C. W. (I972). Methods for studying bacteriocins. In Methods in Microbiology, vol. 7 A, pp. 31 5-422. Edited by J. R. Norris and D. W. Ribbons. London and New York: Academic Press.

ReEves, P. (1972). Molecular Biology, Biochemistry and Biophysics, vol. I I, The Bacteriocins. New York, Heidelberg, and Berlin: Springer-Verlag.

RosLYCKY, E. B. (1967). Bacteriocin production in the rhizobia bacteria. Canadian Journal of Microbiology I3, $43 \mathrm{I}-432$.

SChWINGHAMER, E. A. (I97I). Antagonism between strains of Rhizobium trifolii in culture. Soil Biology and Biochemistry 3, 355-363.

Schwinghamer, E. A., Pankhurst, C. E. \& Whitfeld, P. R. (1973). A phage-like bacteriocin of Rhizobium trifolii. Canadian Journal of Microbiology 19, 359-368.

VeSELL, E. S. \& BEARN, A. G. (I962). Variations in the lactic dehydrogenase of vertebrate erythrocytes. Journal of General Physiology 45, 553-565. 